\title{
Keanekaragaman serangga pengunjung bunga pada tanaman tumpang sari kedelai dengan tanaman orok-orok (Crotalaria juncea)
}

\author{
Diversity of flower visiting insects on intercropping between soybean \\ and sunn hemp (Crotalaria juncea)
}

\author{
Sayekti Kurnia Rahayu ${ }^{1}$, Supriyadi ${ }^{2}$, Supriyono $^{2}$, Retno Wijayanti², \\ Retno Bandriyati Arni Putri ${ }^{2}$ \\ ${ }^{1}$ Program Studi Agronomi, Pascasarjana, Universitas Sebelas Maret \\ Jalan Ir. Sutami 36A Kentingan, Surakarta 57126 \\ ${ }^{2}$ Program Studi Agroteknologi, Fakultas Pertanian, Universitas Sebelas Maret \\ Jalan Ir. Sutami 36A Kentingan, Surakarta 57126 \\ (diterima Juli 2017, disetujui Maret 2018)
}

\begin{abstract}
ABSTRAK
Tumbuhan berbunga dapat meningkatkan populasi serangga polinator, yang sekaligus berperan penting dalam meningkatkan hasil tanaman. Tujuan penelitian ini untuk mengetahui pengaruh tumpang sari Crotalaria juncea dengan kedelai terhadap keanekaragaman serangga pengunjung bunga dan polinator alami terhadap hasil kedelai. Penelitian dirancang pada petak tunggal, dengan perlakuan: tanpa $C$. juncea (kontrol), penanaman $C$. juncea mengelilingi lahan kedelai, penanaman $C$. juncea setiap 5 baris kedelai, dan penanaman $C$. juncea setiap 10 baris kedelai. Pengaruh polinator alami terhadap hasil kedelai diamati melalui penyungkupan tanaman dengan jaring serangga. Hasil penelitian menunjukan, bahwa penanaman $C$. juncea dapat meningkatkan keanekaragaman serangga pengunjung bunga. Indeks keanekaragaman tertinggi 2,37 tercatat pada petak penanaman $C$. juncea setiap 10 baris kedelai. Keanekaragaman serangga pengunjung bunga terbanyak, yaitu 18 spesies ditemukan pada perlakuan penanaman $C$. juncea setiap 5 baris kedelai. Serangga pengunjung bunga yang dominan adalah Coccinella transversalis, Apis mellifera, Xylocopa virginica, Megachile parientina, Megachile relativa, Ropalidia fasciata, dan Vespa sp. Polinator alami (tanpa sungkup) dapat meningkatkan jumlah polong $30,11 \%$, jumlah biji $44,63 \%$, dan berat biji per tanaman $15,44 \%$ sehingga berperanan penting pada hasil kedelai.
\end{abstract}

Kata kunci: modifikasi habitat, polinator alami, keanekaragaman serangga

\begin{abstract}
Flowering plants can enhance the population of insect pollinators as well as crop yields. This study was aimed to determine the effect of intercropping between Crotalaria juncea and soybean on the diversity of flower-visiting insects and the role of wild pollinator to yield of soybean. The study was carried out on a single plot, with the treatment: without planting of $C$. juncea (control), planting of $C$. juncea surrounds of the soybean field, planting of $C$. juncea every 5 rows of soybean and planting of $C$. juncea every 10 rows of soybean. The effect of wild pollinator was identified by bagging the soybean by using insect net. The results revealed that planting of $C$ juncea may increase the diversity of flower-visiting insect. The highest diversity index was 2.37 found on the plot with the planting of $C$. juncea every 10 rows of soybean. The highest diversity of flower-visiting insect was 18 species found in treatment by planting $C$. juncea every 5 rows of soybean. Flower-visting
\end{abstract}

\footnotetext{
*Penulis korespondensi: Supriyadi. Program Studi Agroteknologi, Fakultas Pertanian, Universitas Sebelas Maret (UNS) Surakarta Jalan Ir. Sutami 36 A, Surakarta 57126, Tel/Faks: (0271) 632450, Email supriyadi58@staff.uns.ac.id; priyadi_hpt@yahoo.co.id
} 
insects were dominated by Coccinella transversalis, Apis mellifera, Xylocopa virginica, Megachile parientina, Megachile relativa, Ropalidia fasciata, and Vespa sp. Wild pollinator by the open pollination (without bagging) may increase $30.11 \%$ number of pods, $44.63 \%$ number of seeds, and $15.44 \%$ seed weight per plant, this shows how important the role of wild/insect pollinators.

Key words: diversity of insect, habitat modification, wild pollinator

\section{PENDAHULUAN}

Kedelai merupakan kelompok legum yang dibudidayakan untuk menyediakan bahan pangan pokok (Indrayati \& Umar 2011) dan merupakan sumber protein nabati (Kanchana et al. 2016; Jiao et al. 2012). Badan Pusat Statistik (2015) menyebutkan data produksi kedelai di Indonesia tahun 2015 sebanyak 998,87 ribu ton biji kering. Namun demikian, produksi tersebut masih belum dapat mencukupi kebutuhan pasar. Sasaran utama peningkatan produksi kedelai adalah hasil biji yang tinggi dan bermutu bagus (Kartono 2005). Produksi biji merupakan hasil dari polinasi atau penyerbukan sampai terjadi fertilisasi. Sementara itu, polinasi adalah proses pemindahan polen atau serbuk sari dari kepala sari ke stigma (Liferdi 2008; Widhiono 2015), yang menjadi prasyarat untuk perkembangan buah dan biji (Shivanna 2013).

Kedelai merupakan tanaman autogamic, yaitu bunga tanaman mampu menyerbuk sendiri (Widhiono 2015), tetapi penyerbukan silang dapat terjadi apabila ada bantuan serangga polinator maupun angin (Chiari et al. 2013; Liferdi 2008). Penelitian Chiari et al. (2005) mengungkap bahwa keberadaan lebah madu (Apis mellifera Linnaeus) pada penyerbukan tanaman kedelai dapat meningkatkan hasil biji 58,86\%.

Pemanfaatan serangga polinator guna peningkatan kualitas dan kuantitas produksi tanaman di Indonesia masih kurang mendapatkan perhatian. Penelitian pengaruh tumbuhan berbunga guna peningkatan peran polinator di Indonesia juga masih sangat terbatas. Padahal, penurunan jenis dan populasi serangga polinator kini mulai dirasakan akibat terjadi perubahan dan kerusakan habitat (Erniwati \& Kahono 2010). Selain itu, aplikasi insektisida dalam jangka panjang juga dapat menekan keanekaragaman dan kelimpahan serangga polinator (Supriyadi 2015).

Manajemen habitat sekitar lahan petanian menjadi pilihan sebagai upaya konservasi serangga polinator, misalnya dengan penanaman tumbuhan berbunga (Supriyadi 2015). Tumbuhan berbunga dapat memproduksi nektar dan polen, yang merupakan sumber pakan/pakan tambahan bagi predator, parasitoid dewasa, serta polinator itu sendiri (Landis et al. 2000; Gurr et al. 2004; Supriyadi 2015). Secara umum, nektar dan polen dari spesies tanaman berkerabat dekat menunjukkan kemiripan asam amino (Weiner et al. 2010). Oleh karena itu, tumbuhan Crotalaria juncea yang merupakan tumbuhan berbunga anggota Famili Leguminosae sesuai untuk mendukung keberadaan polinator kedelai. Hal ini sesuai dengan pernyataan Nicholls \& Altieri (2013) bahwa keanekaragaman tumbuhan di dalam dan sekitar area pertanaman dapat menjadi habitat dan menarik bagi lebah serta serangga penyerbuk lainnya sehingga dapat mendorong peningkatan keanekaragaman serta kelimpahan serangga polinator (Landis et al. 2000; Supriyadi 2015).

Berdasarkan hal tersebut, keberadaan tumbuhan berbunga dalam agroekosistem sangat diperlukan guna mendukung berfungsinya layanan ekologi (ecological service), yaitu proses penyerbukan tanaman (Supriyadi 2015). Oleh karena itu, penelitian ini bertujuan untuk mengetahui pengaruh penanaman orok-orok (C. juncea) di pertanaman kedelai terhadap keanekaragaman serangga pengunjung bunga serta peranannya terhadap hasil kedelai.

\section{BAHAN DAN METODE}

Penelitian dilaksanakan di pertanaman kedelai, Kecamatan Bayat Kabupaten Klaten, Jawa Tengah (7047'8'LS $110^{\circ} 40^{\prime} 0^{\prime \prime}$ BT) dari bulan Juli 2016 sampai dengan November 2016. Identifikasi serangga dilakukan di Laboratorium Hama dan Penyakit Tanaman, Fakultas Pertanian, Universitas Sebelas Maret, sedangkan penanganan hasil kedelai dilakukan di Laboratorium Ekologi dan Managemen Produksi Tanaman, Fakultas Pertanian, Universitas Sebelas Maret. 
Pola penanaman tumbuhan berbunga $C$. juncea pada pertanaman kedelai

Penelitian mengadopsi ide Landis et al. (2000), yaitu memodifikasi habitat pertanaman melalui penanaman tumbuhan berbunga. Perlakuan tumpang sari orok-orok (C. juncea) dengan kedelai adalah sebagai berikut: (A). Tanpa penanaman C. juncea (kontrol); (B). Penanaman C. juncea mengelilingi tanaman kedelai; (C) Penanaman $C$. juncea setiap 5 baris tanaman kedelai; dan (D). Penanaman $C$. juncea setiap 10 baris tanaman kedelai (Gambar 1). Luas plot masing-masing perlakuan adalah $400 \mathrm{~m}^{2}$, dengan ukuran panjang dan lebar masing-masing $20 \mathrm{~m}$. Cara bertanam mengacu pada teknologi budi daya kedelai lahan bekas pertanaman padi (Balitkabi 2016) dan tidak ada aplikasi pestisida. Pupuk dasar kompos diberikan pada saat awal tanam.

\section{Keanekaragaman serangga pengunjung bunga}

Pengamatan dilakukan pada 30 tanaman sampel yang dipilih secara acak, dengan pola pengambilan sampel mengikuti garis diagonal (X) pada setiap plot perlakuan, seperti metode Untung (1993). Pengambilan sampel serangga pengunjung bunga dilakukan dengan metode langsung (visual), yakni menangkap serangga yang mengunjungi bunga. Jaring serangga juga digunakan untuk menangkap serangga pengunjung bunga dengan ukuran dan bentuk, seperti dalam penelitian Tauruslina et al. (2015) dan Hendrival et al. (2011). Pengamatan dilakukan dengan internval satu minggu, dimulai saat kedelai umur 3-10 minggu setelah tanam (MST).

\section{Penanganan dan identifikasi serangga pengun- jung bunga}

Penanganan serangga yang ukuran relatif besar dilakukan dengan awetan kering, sedangkan untuk spesimen kecil dengan awetan basah dalam alkohol 70\%. Identifikasi serangga dilakukan dengan bantuan mikroskop binokular mengikuti buku kunci determinasi serangga Borror et al. (1996) dan Britton et al. (1979).

\section{Pengaruh polinator alami terhadap hasil kedelai}

Pengamatan pengaruh polinator alami/ serangga polinator terhadap hasil kedelai dilakukan pada 36 tanaman sampel. Penyungkupan dilakukan dengan kain kasa saat kedelai berbunga (sebagai kontrol) dan tanpa penyungkupan (penyerbukan alami), seperti penelitian Chiari et al. (2005). Penyungkupan dimaksudkan untuk menghindarkan polinasi oleh serangga, tetapi tidak menghalangi angin. Pengamatan komponen hasil kedelai dilakukan saat panen dengan mencatat jumlah polong, jumlah biji, berat 100 biji, dan berat biji per tanaman sampel.

\section{Analisis data}

Pengukuran keanekaragaman serangga pengunjung bunga ditetapkan berdasarkan indeks Shannon $\left(\mathrm{H}^{\prime}\right)$, seperti yang dilakukan Fajarwati et al. (2009) dengan penilaian pembobotan mengikuti skala penilaian Krebs (1989), dengan rumus: Indeks Shannon $\left(H^{\prime}\right)=-\Sigma n_{i} / N \ln \left(n_{i} / N\right)$, dengan $\mathrm{H}$ : indeks keanekaragaman; $\mathrm{n}_{\mathrm{i}}$ : jumlah individu spesies I; dan $\mathrm{N}$ : jumlah total individu seluruh spesies.

Nilai indeks keanekaragaman dibandingkan antar perlakuan untuk mengetahui pengaruhnya terhadap peningkatan keanekaragaman serangga pengunjung bunga. Data komponen hasil kedelai dibandingkan secara deskriptif dengan bantuan grafik, untuk mengidentifkasi pengaruh antar perlakuan.

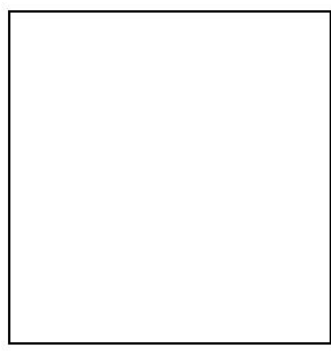

A

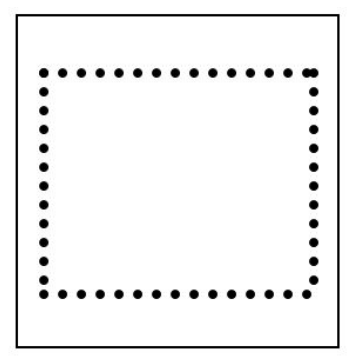

B

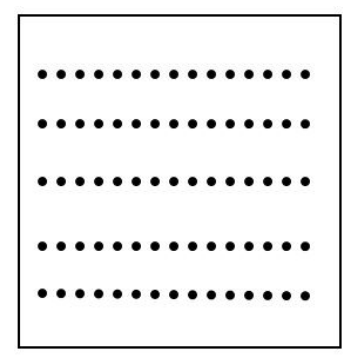

C

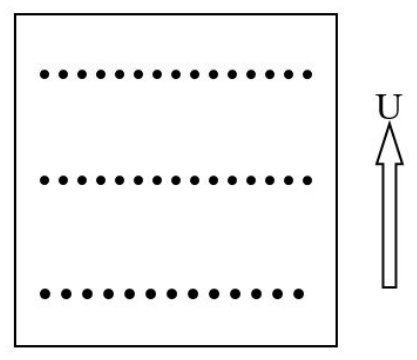

D

Gambar 1. Pola tumpang sari Crotalaria juncea dengan kedelai. A: tanpa penanaman Crotalaria juncea; B: Crotalaria juncea ditanam mengelilingi tanaman kedelai; C. Crotalaria juncea ditanam setiap 5 baris kedelai; dan D. Crotalaria juncea ditanam setiap 10 baris tanaman kedelai. 


\section{HASIL}

\section{Keanekaragaman serangga pengunjung bunga}

Indeks keanekaragaman serangga pengunjung bunga pada plot pertanaman kedelai yang ditanami C. juncea lebih tinggi dibandingkan dengan yang tanpa $C$. juncea. Indeks keanekaragaman serangga pengunjung bunga paling tinggi $(2,37$, kategori keanekaragaman tinggi), tercatat di plot perlakuan penanaman $C$. juncea setiap 10 baris tanaman kedelai, sedangkan nilai keanekaragaman terendah $(2,15$, kategori keanekaragaman tinggi) tercacat pada plot perlakuan dengan penanaman $C$. juncea mengelilingi pertanaman kedelai. Semantara itu, pada plot pertanaman kedelai tanpa $C$. juncea (kontrol), indeks keanekaragamannya hanya 1,56 , kategori keanekaragaman sedang (Tabel 1).

\section{Komposisi serangga pengunjung bunga}

Keanekaragaman serangga pengunjung bunga pada plot pertanaman kedelai yang ditanami Crotalaria juncea lebih tinggi dibandingkan dengan yang tanpa $C$. juncea (kontrol). Jumlah spesies serangga pengunjung bunga paling tinggi, yaitu 18 spesies ditemukan pada plot perlakuan penanaman $C$. juncea setiap 5 baris tanaman kedelai. Jumlah spesies serangga pengunjung bunga berikutnya, berturut-turut 17 spesies pada plot dengan penanaman $C$. juncea setiap 10 baris tanaman kedelai, 15 spesies pada plot dengan penanaman $C$. juncea mengelilingi tanaman kedelai, dan 9 spesies pada plot tanpa penanaman $C$. juncea (Tabel 1).

Serangga pengunjung bunga dari Ordo Hymenoptera adalah Apis mellifera, Apis sp., Xylocopa laticeps, Xylocopa virginica, Megachile parientina, Megachile relative, Megachile centuralis, Priocnemis sp., Ropalidia fasciata, dan Vespa sp. yang merupakan kelompok lebah dan tawon besar. Sementara itu, pengunjung bunga anggota Ordo Coleoptera ada tiga spesies, yaitu Luperodes suturalis, Verania lineate, dan Coccinella transversalis, serta Ordo Diptera (spesies Tricholioproctia hardyi dan Musca domestica).

Tabel 1. Jenis dan kelimpahan serangga pengunjung bunga pada tumpang sari antara Crotalaria juncea dan kedelai

\begin{tabular}{|c|c|c|c|c|c|c|c|c|c|c|}
\hline \multirow{2}{*}{ Ordo } & \multirow{2}{*}{ Famili } & \multirow{2}{*}{ Spesies } & \multicolumn{2}{|c|}{ Petak A } & \multicolumn{2}{|c|}{ Petak B } & \multicolumn{2}{|c|}{ Petak C } & \multicolumn{2}{|c|}{ Petak D } \\
\hline & & & $\sum$ & $\%$ & $\sum$ & $\%$ & $\sum$ & $\%$ & $\sum$ & $\%$ \\
\hline \multirow[t]{3}{*}{ Coleoptera } & Chrysomelidae & Luperodes suturalis & 2 & 33,3 & 2 & 33,3 & 2 & 33,3 & 0 & 0 \\
\hline & Coccinellidae & Verania lineate & 0 & 0 & 4 & 40 & 3 & 30 & 3 & 30 \\
\hline & & Coccinella transversalis & 15 & 20,5 & 18 & 24,7 & 21 & 28,8 & 19 & 26 \\
\hline \multirow[t]{2}{*}{ Diptera } & Muscidae & Musca domestica & 1 & 7,7 & 4 & 30,8 & 3 & 23,1 & 5 & 38,5 \\
\hline & Sarcophagidae & Tricholioproctia hardyi & 0 & 0 & 0 & 0 & 1 & 25 & 3 & 75 \\
\hline \multirow[t]{10}{*}{ Hymenoptera } & Apidae & Apis mellifera & 9 & 45 & 5 & 25 & 4 & 20 & 2 & 10 \\
\hline & & Apis sp. & 0 & 0 & 0 & 0 & 1 & 25 & 3 & 75 \\
\hline & & Xylocopa laticeps & 1 & 16,7 & 2 & 33,3 & 1 & 16,7 & 2 & 33,3 \\
\hline & & Xylocopa virginica & 1 & 7,7 & 4 & 30,8 & 7 & 53,8 & 1 & 7,7 \\
\hline & Megachilidae & Megachile parientina & 0 & 0 & 5 & 16,7 & 7 & 23,3 & 18 & 60 \\
\hline & & Megachile relative & 1 & 5,3 & 6 & 31,6 & 8 & 42,1 & 4 & 21,1 \\
\hline & & Megachile centuralis & 0 & 0 & 2 & 40 & 1 & 20 & 2 & 40 \\
\hline & Pompilidae & Priocnemis sp. & 0 & 0 & 2 & 28,6 & 4 & 57,1 & 1 & 14,3 \\
\hline & Vespidae & Ropalidia fasciata & 0 & 0 & 4 & 40 & 3 & 30 & 3 & 30 \\
\hline & & Vespa sp. & 0 & 0 & 9 & 37,5 & 4 & 16,7 & 11 & 45,8 \\
\hline \multirow[t]{3}{*}{ Lepidotera } & Arctiidae & Amata nigriceps & 0 & 0 & 4 & 50 & 2 & 25 & 2 & 25 \\
\hline & Hesperiidae & Pelopidas lyelli & 3 & 25 & 2 & 16,7 & 1 & 8,3 & 6 & 50 \\
\hline & Lycaenidae & Chliria sp. & 3 & 60 & 0 & 0 & 1 & 20 & 1 & 20 \\
\hline Total individu & & & 36 & 13 & 73 & 26,4 & 74 & 26,8 & 93 & 33,7 \\
\hline Total spesies & & & 9 & 15,3 & 15 & 25,4 & 18 & 30,5 & 17 & 28,8 \\
\hline $\mathrm{H}^{\prime}$ & & & & 56 & & 15 & & 32 & & 37 \\
\hline
\end{tabular}

A: petak kontrol (tanpa Crotalaria juncea); B: petak dengan tumbuhan C. juncea ditanam mengelilingi pertanaman kedelai; C: petak dengan tumbuhan $C$. juncea ditanam setiap 5 baris pertanaman kedelai; dan D: petak dengan tumbuhan $C$. juncea ditanam setiap 10 baris pertanaman kedelai. 
Pengaruh polinator alami terhadap hasil kedelai

Penelitian ini mengungkap adanya pengaruh polinator alami/serangga polinator pada hasil kedelai. Jumlah polong pada kedelai yang disungkup 16,67 polong/tanaman, lebih rendah daripada yang tidak disungkup (21,69 polong/ tanaman). Jumlah biji pada kedelai yang disungkup, yakni 30 biji/tanaman, lebih rendah dari pada biji kedelai yang tidak disungkup (43,39 biji/tanaman). Hasil berat biji kedelai yang disungkup, yakni 4,08 gram/tanaman, juga lebih rendah daripada berat biji kedelai yang tidak disungkup, $(4,71$ gram/tanaman). Namun demikian, hasil berbeda terjadi pada berat 100 biji, yakni 13,61 gram pada perlakuan kedelai yang disungkup lebih tinggi daripada berat biji kedelai yang tidak disungkup (11,04 gram) (Gambar 2).

\section{PEMBAHASAN}

\section{Pengaruh perlakuan $C$. juncea terhadap serangga pengunjung bunga}

Secara keseluruhan, dalam penelitian ini diperoleh informasi bahwa indeks keanekaragaman
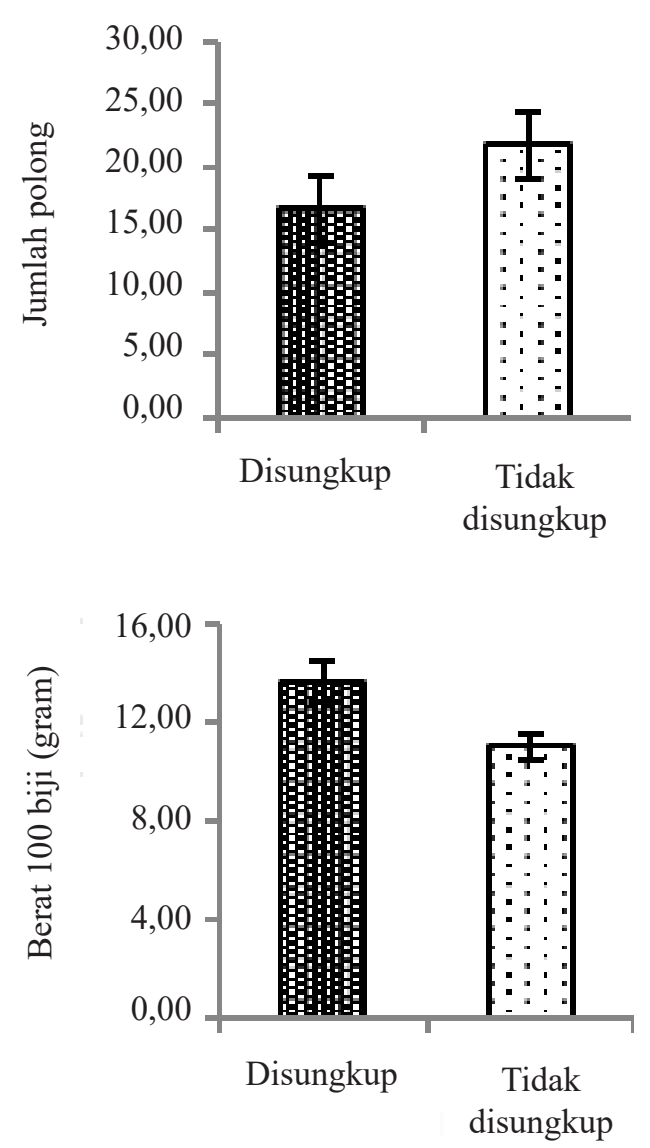

serangga pengunjung bunga pada plot pertanaman kedelai yang ditanami $C$. juncea lebih tinggi dibandingkan dengan yang tanpa $C$. juncea. Penanaman $C$. juncea pada pertanaman kedelai tersebut dapat menjadi mikro habitat yang sesuai sehingga menarik keberadaan serangga. Keanekaragaman yang tinggi umumnya menjadikan ekosistem yang lebih stabil dan interaksi yang lebih intens (Indriyati \& Wibowo 2008; Rogers et al. 2014; Yuniar \& Haneda 2015). Keberadaan tumbuhan berbunga, seperti $C$. juncea sekitar area pertanaman dapat menyediakan nektar dan polen (Nicholls \& Altieri 2013; Landis et al. 2000; Gurr et al.2004) guna mendukung kehidupan serangga polinator. Jenis tumbuhan berbunga yang lebih beragam akan memikat serangga penyerbuk sehingga dapat meningkatkan kunjungan pada bunga dalam komunitas tumbuhan di ekosistem tersebut (Chmura et al. 2013).

Dalam penelitian ini, kumbang spesies $V$. lineate dan C. transversalis (Coleoptera) menunjukkan aktivitas makan pada bunga kedelai sehingga dimasukkan sebagai serangga pengunjung bunga kedelai. Pada padi dan jagung, kedua jenis kumbang tersebut disebutkan memakan polen dan
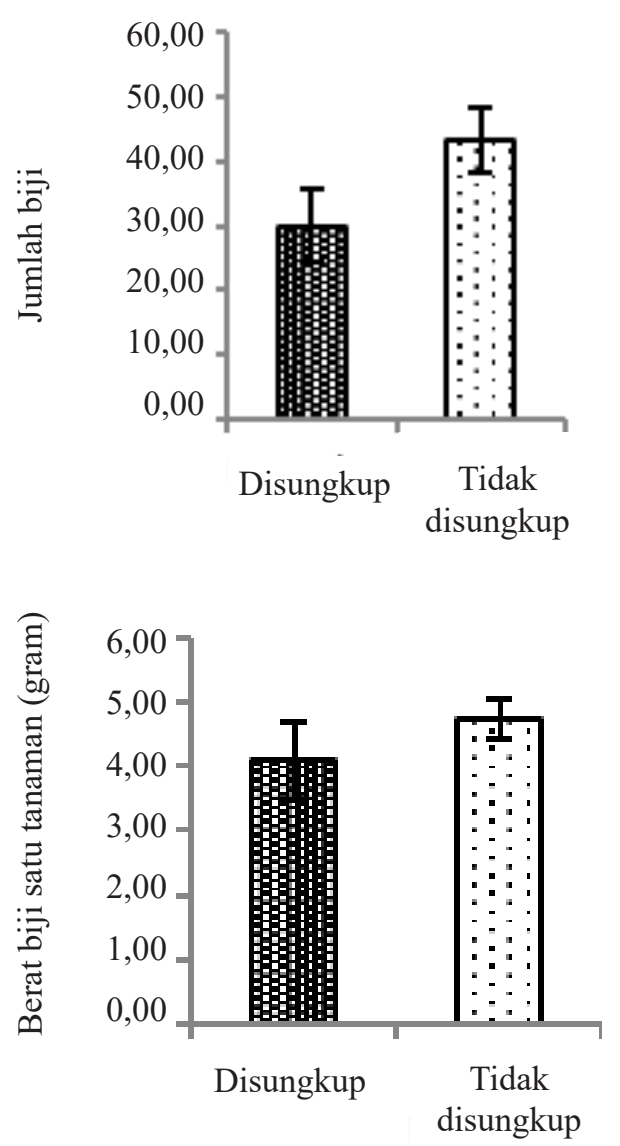

Gambar 2. Pengaruh polinator alamı terhadap hasil kedelai pada tumpang sari antara Crotalaria juncea dan kedelai. 
serangga kecil (Kalshoven 1981). Sementara itu, lalat jenis $M$. domestica telah diidentifkasi dapat membantu proses penyerbukan pada tanaman jarak (Douka \& Fohouo 2014).

Kumbang Xylocopa sp. tercatat sebagai pengunjung bunga kedelai. Kumbang tersebut juga dicatat mengunjungi kacang tunggak (Vigna unguiculata) (Stephanie et al. (2015) dan buncis (Phaseolus vulgaris) (Kingha et al. 2012) untuk mencari nektar dan serbuk sari. Widhiono \& Sudiana (2015) juga menyebutkan bahwa bunga kedelai yang berwarna putih dikunjungi oleh berbagai serangga polinator, yakni Apis sp., M. relativa, $X$. laticeps, dan $R$. fasciata. Sementara itu, Fajarwati et al. (2009) mengamati ngengat Amata sp. (Lepidoptera) sering mengunjungi bunga tomat. Anggota Famili Lycaenidae (Lepidoptera) dilaporkan oleh Kamel et al. (2015) sebagai serangga penyerbuk pada Brassica napus L. Hal tersebut menunjukkan bahwa ekosistem dengan tumbuhan berbunga yang lebih beragam akan lebih memikat serangga penyerbuk (Chmura et al. 2013; Landis et al. 2000).

\section{Pengaruh serangga polinator terhadap hasil kedelai}

Penelitian ini juga mengungkap adanya pengaruh serangga polinator pada hasil kedelai. Hasil ini mirip dengan penelitian Stanley et al. (2013) bahwa serangga polinator, yakni kumbang Xylocopa sp. dapat meningkatkan jumlah biji kacang tunggak (V. unguiculata) $13,58 \%$. Aktivitas lebah $A$. mellifera juga dapat meningkatkan hasil biji kedelai 58,86\% (Chiari et al. 2005) dan meningkatkan jumlah polong buncis ( $P$. vulgaris) $15,58 \%$ (Kingha et al. 2012). Dalam penelitian ini, berat 100 biji kedelai pada perlakuan penyungkupan lebih besar dibandingkan dengan berat biji kedelai tidak disungkup. Hal ini diduga berkaitan dengan jumlah biji/tanaman pada kedelai yang disungkup labih sedikit sehingga fotosintat ditranslokasikan sepenuhnya biji yang sedikit tersebut. Sarawa \& Baco (2014) menyatakan adanya kaitan antara distrubusi dan akumulasi fotosintat dengan bagian tanaman yang akan dipanen karena fotosintat merupakan hasil fotosintesis dan ditranslokasikan ke bagian tanaman yang membutuhkan pada masa vegetatif ataupun generatif. Hal ini juga didukung data penelitian ini bahwa, jumlah biji/tanaman kedelai yang tidak disungkup lebih tinggi daripada kedelai yang disungkup.

\section{KESIMPULAN}

Penanaman C. juncea setiap 10 baris tanaman kedelai dapat meningkatkan keanekaragaman serangga pengunjung bunga kedelai, dengan indeks keanekaragaman mencapai 2,37 (keanekaragaman tinggi). Jenis serangga pengunjung bunga kedelai yang dominan adalah $C$. transversalis, $A$. mellifera, $X$. virginica, $M$. parientina, $M$. relative, R. fasciata, dan Vespa sp. Polinator alami dapat meningkatkan jumlah polong kedelai, jumlah biji, dan berat biji, berturut-turut $30,11,44,63$, dan $15,44 \%$ per tanaman.

\section{UCAPAN TERIMA KASIH}

Pelaksanaan penelitian ini mendapatkan dukungan finansial dari Program Penelitian dan Pengabdian PNBP Universitas Sebelas Maret (UNS), Surakarta, dengan Nomor kontrak: 623/ UN27.21/PP/2016.

\section{DAFTAR PUSTAKA}

Balitkabi. 2016. Teknologi produksi kedelai untuk lahan sawah, lahan kering masam, dan lahan pasang surut tipe C dan D. Available at: http:// balitkabi.litbang.pertanian.go.id/images/ stories/uploads/publikasi/buku/tekprod_15/ tekprod_15_bab_1.pdf. [accessed 1 March 2017].

Borror DJ, Triplehorn CA, Johnson NF. 1996. Pengenalan Pelajaran Serangga. $6^{\text {th }}$ ed. Yogyakarta: Gadjah Mada University Press.

Badan Pusat Statistik. 2015. Produksi Kedelai. Available at: https://www.bps.go.id/Brs/view/ $\mathrm{id} / 1157$ [accessed 21 July 2016].

Britton E, Brown WL, Calaby JH, Colless DH, Common IFB. 1979. The Insect of Australia. Canberra: Melbourne University Press.

Chiari WC, Hoffmann-Campo CB, Arias CA, Lopes TS, Toledo TCOA, Chambó ED, RuvoloTakasusuki MCC, Toledo VAA. 2013. Floral biology and Africanized honeybee behaviour in transgenic (Roundup Ready ${ }^{\mathrm{TM}}$ var. BR-245 RR) and conventional (var. BRS-133) soybean 
(Glycine $\max$ L. Merrill) flowers. In: Price A, Kelton JA (Eds.), Herbicides-Advances in Research. pp 277-298. Rijeka: InTech. doi: http://dx.doi.org/10.5772/55847.

Chiari WC, Toledo VAA, Takasuki MCCR, Oliveira AJB, Sakaguti ES, Attencia VM, Costa FM, et al. 2005. Pollination of soybean (Glycinemax L.Merril) by Honeybees (Apis melliffera L.). Brazilian Archives of Biology and Technology 48:34-36.

Chmura D, Adamski P, Denisiuk Z. 2013. How do plant communities and flower visitors relate? A case study of semi-natural Xerothermic Grasslands. Acta Societatis Botanicorum Polonia 82:99-105. doi: https://doi.org/10.5586/ asbp.2013.015.

Douka C, Fohouo FNT. 2014. Foraging and pollination activity of Musca domestica L. (Diptera: Muscidae) on flowers of Ricinuscommunis L. (Euphorbiaceae) at Maroua, Cameroon. Journal of Biodiversity and Environmental Sciences 4:67-76.

Erniwati, Kahono S. 2010. Keragaman serangga pengunjung bunga pada lima jenis tanaman buah di Jawa Timur. Zoo Indonesia 20:27-38.

Fajarwati MR, Atmowidi T, Dorly. 2009. Keragaman serangga pada bunga tomat (Lycopersiconesculentum Mill.) di lahan pertanian organik. Jurnal Entomologi Indonesia 6:77-85. doi: https://doi.org/10.5994/jei.6.2.77.

Gurr GM, Scarratt SL, Wratten SD, Berndt L, Irvin N. 2004. Ecological engineering, habitat manipulation and pest management. In: Gurr GM, Wratten SD, Altieri MA (Eds.), Ecological Engineering for Pest Management Advances in Habitat Manipulation for Arthropods. pp. 1-12. Collingwood VIC: CSIRO Publishing.

Hendrival, Hidayat P, Nurmansyah A. 2011. Keragaman dan kelimpahan musuh alami Bemisia tabaci (Gennadius) (Hemiptera: Aleyrodidae) pada pertanaman cabai merah di Kecamatan Pakem, Kabupaten Sleman, Daerah Istimewa Yogyakarta. Jurnal Entomologi Indonesia 8:96109. doi: https://doi.org/10.5994/jei.8.2.96-109.

Indrayati L, Umar S. 2011. Pengaruh pemupukan N, P, $\mathrm{K}$ dan bahan organik terhadap pertumbuhan dan hasil kedelai di lahan sulfat masam bergambut. Agrista 15:94-101.

Indriyati, Wibowo L. 2008. Keragaman dan kemelimpahan Collembola serta Arthropoda tanah di lahan sawah organik dan konvensional pada masa bera. Jurnal Hama dan Penyakit Tumbuhan 8:110-116.
Jiao Z, Si X, Zhang Z, Li G, Cai Z. 2012. Compositional study of different soybean (Glycine max L.) varieties By $1 \mathrm{H}$ NMR spectroscopy, chromatographic and spectrometric techniques. Food Chemistry 135:285-291.

Kalshoven. 1981. Pets of Crops in Indonesia. Jakarta: PT. Ichtiar Baru.

Kamel SM, Mahfouz HM, Blal AEH, Said M, Mahmoud MF. 2015. Diversity of insect pollinators with reference to their impact on yield production of canola (Brassica napus L.) in Ismailia, Egypt. Journal Pesticides and Phytomedicine 30:161-168.

Kanchana L, Santha M, Raja K. 2016. A review on Glycine $\max$ (L.) Merr. (Soybean). World Journal of Pharmacy and Pharmaceutical Sciences 5:356-371.

Kartono. 2005. Persilangan buatan pada empat varietas kedelai. Buletin Teknik Pertanian 10:49-52.

Kingha BMT, Fohouo FNT, Ngakou A, Brückner D. 2012. Foraging and pollination activities of Xylocopa olivacea (Hymenoptera, Apidae) on Phaseolus vulgaris (Fabaceae) Flowers at Dang (Ngaoundere-Cameroon). Journal of Agricultural Extension and Rural Development 4:330-339.

Krebs CJ. 1989. Ecological Methodology. New York: Harper Collins.

Landis DA, Wratten SD, Gurr GM. 2000. Habitat management to conserve natural enemies of arthropod pets in agricultural. Annual Review of Entomology 45:175-201. doi: https://doi. org/10.1146/annurev.ento.45.1.175.

Liferdi. 2008. Lebah polinator utama pada tanaman hortikultura. Iptek Hotikultura 4:1-5.

Nicholls CI, Altieri MA. 2013. Plant biodiversity enhances bees and other insect pollinators in agroecosystems. Agronomy for Sustainable Development 33:257-274. doi: https://doi. org/10.1007/s13593-012-0092-y.

Rogers SR, Tarpy DR, Burrack HJ. 2014. Bee species diversity enhances productivity and stability in a perennial crop. Plos One 9:1-8.

Sarawa, Baco AR. 2014. Partisi fotosintat beberapa kultivar kedelai (Glycine max. (L.) Merr.) pada ultisol. Jurnal Agroteknos 4:152-159.

Shivanna K. 2013. Pollen Biology and Biotechnology. New Hampshire: Science Publishers Inc. Envield.

Stanley DA, Gunning D, Stout JC. 2013. Pollinators and pollination of oilseed rape crops (Brassica napus L.) in Ireland: ecological and economic 
incentives for pollinator conservation. Journal Insect Conservation 17:1181-1189.

Stephanie KB, Albert N, Nestor TFF. 2015. Pollination and yield attributes of (cowpea) Vigna unguiculata L. Walp. (Fabaceae) as influenced by the foraging activity of Xylocopa olivacea Fabricius (Hymenoptera: Apidae) and inoculation with Rhizobium in Ngaoundere, Cameroon. International Journal of Agronomy and Agricultural Research 6:62-76.

Supriyadi. 2015. Keragaman tumbuhan berbunga di agroekosistem untuk meningkatkan fungsi layanan ekologi. Di dalam: Supriyono, Purnomo D, Yuniastuti E, Parjanto (Eds.), Proseding Seminar Nasional Perhimpunan Agronomi Indonesia: Penguatan Ketahanan Pangan dalam Menghadapi Perubahan Iklim (Surakarta:13-14 November 2014). pp. 486-491. Surakarta: Perhimpunan Agronomi Indonesia.

Tauruslina AE, Trizelia, Yaherwandi, Hamid H. 2015. Analisis keragaman hayati musuh alami pada eksosistem padi sawah di daerah endemik dan non-endemik wereng batang cokelat Nilaparvata lugens di Sumatera Barat. Di dalam: Prosiding Seminar Nasional Masyarakat Biodiversitas Indonesia Vol. 1 No. 3, (Yogyakarta, 21 Maret 2015). pp. 581-589. Yogyakarta: Masyarakat Biodiversitas Indonesia.

Untung K. 1993. Pengantar Pengelolaan Hama Terpadu. Yogyakarta: Gadjah Mada University Press.

Weiner CN, Hilpert A, Werner M, Lisenmair KE, Bluthgen N. 2010. Pollen amino acids and flower specialization in solitary bees. Apidologie 41:476-487. https://doi.org/10.1051/ apido/2009083.

Widhiono I. 2015. Strategi Konservasi Serangga Pollinator. Purwokerto: Universitas Jenderal Soedirman.

Widhiono I, Sudiana E. 2015. Keragaman serangga penyerbuk dan hubunganya dengan warna bunga pada tanaman pertanian di Lereng Utara Gunung Slamet, Jawa Tengah. Biospecies 8:43-50.

Haneda NF. Yuniar N. 2015. Keanekaragaman semut (Hymenoptera: Formicidae) pada empat tipe ekosistem yang berbeda di Jambi. Jurnal Silvikultur Tropika 6:203-209 